\title{
Aplikasi Rekam Medis Elektronik Ibu Hamil
}

\author{
Tominanto $^{1}$, Tria Puspita Sari ${ }^{2}$ \\ ${ }^{1}$ Fakultas Ilmu Kesehatan Universitas Duta Bangsa Surakarta, \\ ${ }^{2}$ ITS PKU Muhammadiyah Surakarta \\ Email : ${ }^{1}$ tominanto@udb.ac.id ${ }^{2}$ triapipit20@gmail.com
}

\begin{abstract}
The authority and obligations of midwife practices in Indonesia are regulated in the Decree of the Minister of Health of the Republic of Indonesia No.900 / Menkes / SK / VII / 2002 concerning Registration and Practice of Midwives. Delivery assistance allowed by midwives are normal and emergency deliveries, and basic health services only deal with minor cases that are within their capabilities. Implementation of midwife practice services found many problems regarding the management of medical records of pregnant women that have not been optimal, including: incomplete medical records, difficulties in searching for medical record data, less synchronous data, recording and reporting of basic health services that are often too late. This can result in a decrease in the quality of health services for pregnant mother patients until delivery. An alternative solution to this problem is to develop an electronic medical record application for pregnant women that can present a complete and accurate history of the examination and development of the health of pregnant women so as to improve the health services of pregnant women and facilitate the reporting process to related parties. The method of developing an electronic medical record application for pregnant women uses the waterfall method with stages of development: system requirements analysis, system design, implementation and system testing. The programming language used by PHP and MySQL databases. This application program consists of 1) data input for pregnant women, 2) input for examining pregnant women, 3) input medical treatment, and 4) report on examination results. The test results show that this application can store and present information about the health history of pregnant women with a valid so that it can be used as an alternative service for medical records of pregnant women that is more optimal.
\end{abstract}

Keywords:Electronic Medical Record, Pregnant Women, Midwife, Health, Waterfall

\section{PENDAHULUAN}

Dewasa ini, pelayanan kesehatan yang cepat, berkualitas dan terjangkau menjadi tuntutan utama masyarakat. Salah satu faktor penting untuk memenuhi hal tersebut adalah penyelenggaraan rekam medis yang berkualitas. Rekam medis menurut Peraturan Menteri Kesehatan No.269/MENKES/PER/III/2008 adalah berkas yang berisikan catatan atau dokumen tentang pasien, pemeriksaan, pengobatan, tindakan dan pelayanan lain yang diberikan kepada pasien selama masa perawatan [1]. Tercapainya tertib administrasi dalam rangka upaya peningkatan pelayanan kesehatan merupakan salah satu tujuan rekam medis.

Definisi Rekam Medis Elektronik atau RME adalah penggunaan perangkat teknologi informasi untuk pengumpulan, penyimpanan, pengolahan serta pengaksesan data rekam medis pasien dalam suatu sistem manajemen basis data yang menghimpun berbagai sumber data medis [2]. Pengelolaan rekam medis menggunakan RME dapat menyajikan informasi riwayat pemeriksaan, pengobatan dan perkembangan kesehatan pasien secara cepat dan akurat sehingga dapat meningkatkan pelayanan kesehatan lanjutan yang lebih berkualitas.

Wewenang dan kewajiban bidan, diatur dalam Kepmenkes RI No.900/Menkes/SK/VII/2002 tentang Registrasi dan Praktik Bidan. Pertolongan persalinan yang diperbolehkan dilakukan oleh bidan yaitu persalinan normal dan kegawatdaruratan, dan pelayanan kesehatan dasar hanya mengatasi kasus-kasus ringan yang sesuai dengan kemampuan. Bidan yang menjalankan Praktik 
harus memiliki Surat Izin Praktik Bidan (SIPB) sehingga dapat menjalankan Praktik pada saran kesehatan atau program [3].

Pelayanan yang di berikan pada praktik bidan meliputi penyuluhan kesehatan, konseling $\mathrm{KB}$, antenatal care, senam hamil, perawatan payudara, asuhan persalinan, perawatan nifas, perawatan bayi, pelayanan KB ( IUD, AKBK, Suntik, Pil), imunisasi (ibu dan bayi), kesehatan reproduksi remaja, perawatan pasca keguguran. Selain itu praktik bidan melayani pemeriksaan untuk orang yang sakit, kemudian memberi pelayanan kesehatan terhadap wanita usia subur serta lanjut usia [3]. Dari sekian banyak pelayanan yang dapat diberikan ini yang menjadi pelayanan utama praktik bidan adalah pelayanan kesehatan untuk ibu hamil.

Tingginya permintaan masyarakat terhadap peran aktif bidan dalam memberikan pelayanan kesehatan terus meningkat. Hal ini menuntut Bidan untuk selalu berusaha meningkatkan kemampuan sekaligus mempertahankan dan meningkatkan kualitas pelayanannya khususnya pelayanan kesehatan ibu hamil, KB dan kesehatan reproduksi. Melalui pelayanan berkualitas dan terjangkau yang diberikan oleh Bidan, kepuasan pelanggan baik kepada individu, keluarga dan masyarakat dapat tercapai [4].

Praktik bidan dalam memberikan pelayanan kesehatan khususnya kepada ibu hamil membutuhkan pengelolaan rekam medis yang berkualitas. Hal ini diperlukan karena rekam medis ibu hamil merupakan informasi utama yang dibutuhkan seorang bidan dalam memantau riwayat kesehatan ibu hamil untuk menentukan tindakan pelayanan medis dan pengobatan selama masa kehamilan hingga persalinan. Rekam medis ibu hamil juga masih terus diperlukan untuk keperluan pelayanan kesehatan pasca persalinan, keperluan rujukan dan pelayanan kesehatan lainnya untuk masa yang akan datang.

Pencatatan rekam medis ibu hamil yang dilakukan secara manual sering menyulitkan bidan untuk mencari data rekam medis untuk setiap pasien ibu hamil dari awal periksa hingga pemeriksaan terakhir. Buku catatan pemeriksaan tersebut juga hanya mencatat data rekam medis yang sangat sederhana, bahkan identitas ibu hamil tidak dicatat dengan lengkap. Pada saat dibutuhkan data rekam medis ibu hamil untuk kepentingan rujukan, dan pelayanan kesehatan selanjutnya juga sangat sulit didapatkan.

Sementara itu standar pelayanan asuhan kebidanan untuk ibu hamil minimal terdiri atas 6 standar : identifikasi ibu hamil, pemeriksaan dan pemantauan antenatal, palpasi abdominal, pengelolaan anemia pada kehamilan, pengelolaan dini hipertensi pada kehamilan, dan persiapan persalinan [5]. Standar ini merupakan standar minimal pelayanan kesehatan ibu hamil yang harus diberikan secara lengkap serta didokumentasikan secara baik sebagai rekam medis ibu hamil untuk keperluan kesinambungan pelayanan (continuity of care).

Berdasarkan uraian tersebut di atas diperlukan pengembangan aplikasi rekam medis elektronik ibu hamil untuk meningkatkan kualitas pelayanan kesehatan ibu hamil sampai dengan persalinan, pelayanan kesehatan selanjutnya yang berkesinambungan dan pelaporan yang lebih lengkap, akurat dan tepat waktu.

Penelitian pengembangan rekam medis elektronik telah banyak dilakukan antara lain penelitian [6],[7],[8],[9],[10]. Penelitian tersebut mengembangkan rekam medis elektronik untuk menyelesaikan permasalahan pengelolaan rekam medis dengan menggunakan berbagai metode, namun sebagian besar menghasilkan kesimpulan bahwa rekam medis elektronik dapat meningkatkan pelayanan kesehatan pasien. Adapun dalam penelitian ini mengembangkan aplikasi rekam medis elektronik yang berfokus pada permasalahan pelayanan rekam medis rawat ibu hamil dengan menggunakan metode pengembangan perangkat lunak waterfall [11], bahasa pemrograman PHP dan basis data MySQL. 


\section{METODE PENELITIAN}

Metode pengembangan perangkat lunak rekam medis elektronik ibu hamil ini menggunakan tahapan waterfall seperti gambar 1 ini :



Gambar 1. Metode Waterfall [12]

Metode waterfall menggunakan tahapan pengembangan sistem yang dilaksanakan secara berurutan dari tahap identifikasi, analisis, desain, implementasi dan pengujian. Jika dalam sebuah tahapan terdapat kesalahan maka dapat diulang kembali ke tahap sebelumnya atau ke tahap yang lebih awal. Setelah itu dilanjutkan kembali ke tahap berikutnya sampai dengan aplikasi rekam medis elektronik ibu hamil berhasil dalam tahap pengujian sistem.

\section{HASIL DAN PEMBAHASAN}

a. Analisis dan Perancangan Sistem

Hasil analisis dan perancangan sistem dalam pengembangan aplikasi rekam medis elektronik ibu hamil ini antara lain disajikan dalam bentuk flowchart sistem seperti gambar 2 berikut ini :



Gambar 2. Flowchart sistem rekam medis elektronik ibu hamil

Gambar 2 tersebut menunjukkan alur sistem pelayanan rekam medis ibu hamil menggunakan aplikasi rekam medis elektronik ibu hamil. Ibu hamil yang berkunjung untuk periksa kesehatan dibedakan menjadi dua, sebagai pasien baru atau pasien lama. Jika sebagai pasien baru maka data identitas ibu hamil diinputkan ke aplikasi dan jika pasien lama maka data indentitas dicari melalui aplikasi dengan kata kunci pencarian nomor rekam medis, nama, tanggal lahir atau alamat ibu hamil. Tahap selanjutnya adalah proses pemeriksaan dan pengobatan, pada proses ini bidan dapat membaca riwayat pemeriksaan dan pengobatan ibu hamil melalui aplikasi, kemudian setelah hasil pemeriksaan dan pengobatan diinputkan ke aplikasi dan disimpan dalam basis data. Proses cetak laporan dapat dilakukan melalui aplikasi baik cetak ke layar maupun cetak ke file dan ke kertas. 
Adapun perancangan juga disajikan dalam Use Case Diagram seperti ditunjukkan pada gambar 3 berikut ini :

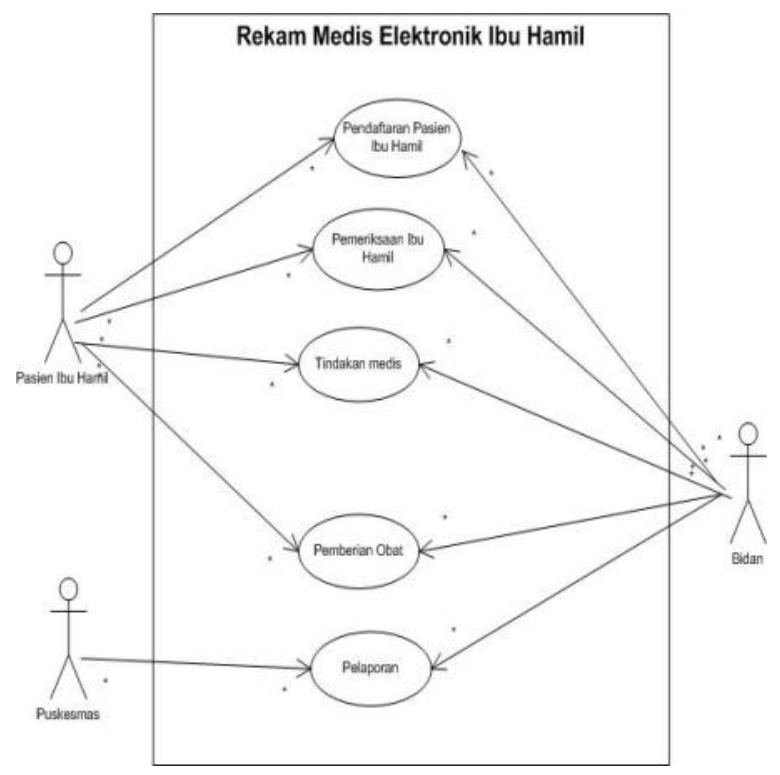

Gambar 3. Use Case Diagram rekam medis elektronik ibu hamil

Use Case Diagram rekam medis elektronik ibu hamil pada gambar 3 terdapat minimum 3 aktor yaitu : Pasien Ibu Hamil, Bidan, dan Puskesmas. Proses pertama dimulai pasien ibu hamil yang melakukan pendaftaran yang dilayani langsung oleh bidan, dilanjutkan proses kedua ibu hamil mendapatkan pelayanan pemeriksaan dan tindakan medis dari bidan. Proses ketiga adalah proses pemberian obat oleh bidan dan proses terakhir adalah bidan mencetak laporan untuk disampaikan ke Puskesmas. Proses-proses pada Use Case Diagram tersebut dilaksanakan secara elektronik dan terhubung dalam basisdata rekam medis elektronik ibu hamil.

\section{b. Implementasi Sistem}

Aplikasi rekam medis elektronik ibu hamil dibuat dengan menggunakan bahasa pemrograman PHP dan basis data mySQL yang antara lain hasilnya adalah sebagai berikut :

a. Input data identitas pasien ibu hamil

Data identitas pasien ibu hamil merupakan data master berfungsi untuk melakukan pencatatan data pribadi pasien ibu hamil. Pada form ini terdapat 3 proses, yaitu data baru yang digunakan untuk menambahkan data pasien baru, edit data digunakan untuk memperbarui data, serta tombol hapus data untuk melakukan penghapusan data pasien ibu hamil. pada form ini terdapat kotak pencarian berdasarkan nama dan alamat pasien.



Gambar 4. Input identitas pasien ibu hamil

Apabila melakukan penambahan data pasien, klik tombol data baru, maka akan muncul dialog yang berisi item identitas pasien ibu hamil yang perlu diisi. Lengkapi isian yang ada, tekan tombol Save untuk menyimpan data.

b. Input data pemeriksaan kehamilan dan tindakan medis

Input data pemeriksaan dan tindakan kehamilan merupakan proses transaksi. Form ini digunakan untuk melakukan pencatatan terhadap kondisi kesehatan pasien, tindakan medis yang diberikan, mulai kunjungan pertama kehamilan sampai dengan persalinan. Pada form ini data yang tampil terdapat 2 warna, yaitu warna hitam dan warna biru. Warna biru berarti pasien tersebut sudah melakukan persalinan, sementara data yang berwarna hitam belum melakukan persalinan. Apabila akan dilakukan pemeriksaan awal terhadap kunjungan pertama pasien, maka dapat dipilih tombol data baru, bila akan melakukan pembaruan data, dapat dipilih tombol edit data, serta tombol hapus data digunakan untuk melakukan penghapusan data. 




Gambar 5. Input pemeriksaan kehamilan

Proses input pemeriksaan kehamilan terdapat 3 proses yaitu pemeriksaan awal, pmeriksaan fisik dan input persalinan. Pemeriksaan awal digunakan untuk melakukan pencatatan terhadap kunjungan pertama pasien, cari nama pasien pada kotak isian, kemudian pilih pasien, maka akan tampil data identitas pasien. lakukan penginputan pada semua item yang sesuai. Untuk mengetahui HPL, isikan tanggal HPHT pasien, kemudian klik pada isian HPL, maka tanggal HPL akan otomatis ditampilkan. Pemeriksaan fisik digunakan untuk melakukan pencatatan pemeriksaan pasien pada setiap kali pasien berkunjung. Klik kanan pada data kunjungan, maka akan ditampilkan dialog seperti gambar diatas. Kemudian lakukan pengisian pada item yang sesuai. Kemudian klik tombol Save. Input persalinan digunakan untuk melakukan pencatatan persalinan pasien. setelah pasien dikatakan sudah melakukan persalinan, dan data persalinan tersebut sudah di isi, hal ini akan menandai bahwa pasien pada kehamilan tersebut sudah berakhir, sehingga data pemeriksaan fisik tidak dapat ditambahkan lagi pada kehamilan tersebut

\section{c. Lihat atau cetak data pemeriksaan}

Untuk mengetahui riwayat pemeriksaan pasien lampau, maka pada data pemeriksaan klik kanan pada data, lalu pilih riwayat pemeriksaan, maka akan ditampilkan dialog seperti gambar berikut, lalu pilih tanggal kunjungan yang akan ditampilkan riwayatnya, kemudian pilih tombol detail, maka data riwayat akan ditampilkan dalam bentuk file PDF.

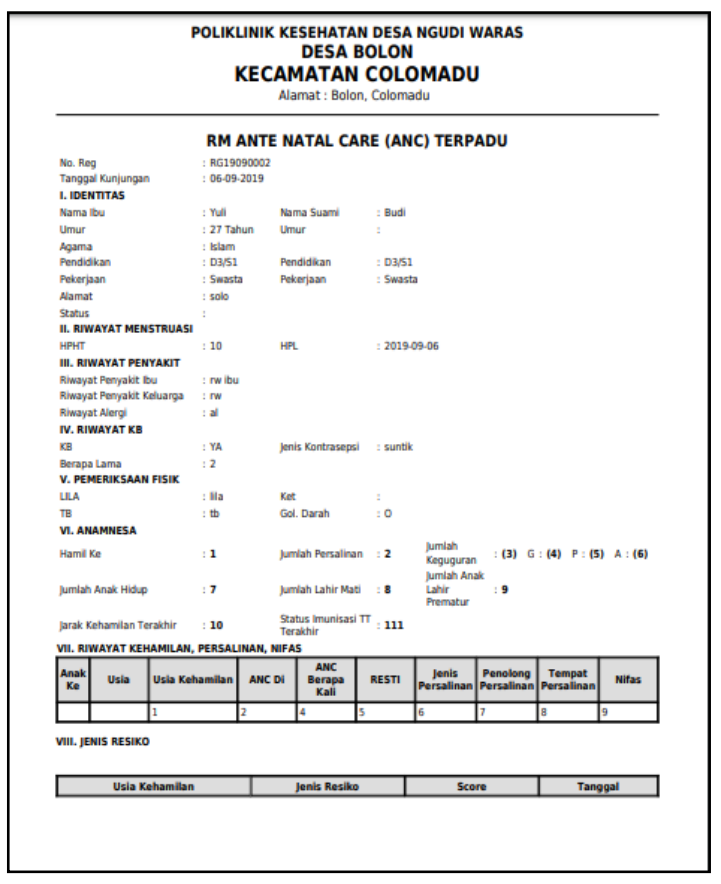

Gambar 6. Cetak data pemeriksaan

\section{c. Pengujian Sistem}

Perangkat lunak aplikasi rekam medis elektronik ibu hamil ini diuji dengan metode Black Box Testing. Sistem pengujian ini lebih menekankan menguji fungsional program dan pemeriksaan data input dan data output [13]. Hasil pengujian aplikasi rekam medis elektronik ibu hamil ditunjukkan pada tabel 1 berikut ini :

Tabel 1. Hasil Pengujian Aplikasi

\begin{tabular}{|l|l|c|c|}
\hline No & \multicolumn{1}{|c|}{ Nama Proses } & $\begin{array}{c}\text { Jumlah } \\
\text { Error }\end{array}$ & Ketangan \\
\hline 1 & Login/password & 0 & Valid \\
\hline 2 & $\begin{array}{l}\text { Input identitas } \\
\text { bu hamil }\end{array}$ & 0 & Valid \\
\hline 3 & $\begin{array}{l}\text { Input } \\
\text { pemeriksaan } \\
\text { awal ibu hamil }\end{array}$ & 0 & Valid \\
\hline 4 & $\begin{array}{l}\text { Input } \\
\text { pemeriksaan } \\
\text { fisik ibu hamil }\end{array}$ & 0 & Valid \\
\hline 5 & $\begin{array}{l}\text { Input } \\
\text { pemeriksaan } \\
\text { berkala } \\
\text { hamil ibu }\end{array}$ & 0 & Valid \\
\hline 6 & Input persalinan & 0 & Valid \\
\hline
\end{tabular}




\begin{tabular}{|l|l|c|c|}
\hline 7 & $\begin{array}{l}\text { Cetak riwayat } \\
\text { pemeriksaan ibu } \\
\text { hamil }\end{array}$ & 0 & Valid \\
\hline 8 & Cetak laporan & 0 & Valid \\
\hline
\end{tabular}

Pengujian dilakukan dengan menginput sejumlah data untuk setiap proses. Semua hasil pengujian menunjukkan perangkat lunak rekam medis elektronik ibu hamil ini telah berjalan dengan benar sesuai yang dirancang dan tanpa terjadi error. Data yang diinputkan tersimpan valid ke basis data dan dapat menghasilkan output yang valid.

\section{KESIMPULAN DAN SARAN}

Aplikasi rekam medis elektronik ibu hamil ini dikembangkan dengan metode waterfall dan menggunakan bahasa pemrograman PHP serta basis data MySQL. Terdapat beberapa proses : input identitas pasien ibu hamil, input proses pemeriksaan, input tindakan medis, input persalinan, cetak riwayat pemeriksan dan cetak laporan. Hasil pengujian aplikasi ini dapat menyimpan dan menyajikan kembali informasi riwayat kesehatan pasien ibu hamil dengan valid sesuai dengan yang diharapkan.

Bagi penelitian selanjutnya dapat dikembangkan aplikasi sejenis dengan metode dan bahasa pemrograman yang berbeda sehingga dapat dibandingkan hasilnya. Selain itu perlu dikembangkan konektivitas aplikasi rekam medis elektronik ibu hamil ini dengan sistem kesehatan yang lain misalnya dengan SIMPUS di Puskesmas.

\section{UCAPAN TERIMA KASIH}

Publikasi ilmiah ini merupakan salah satu luaran dari hasil program pengabdian kepada masyarakat skema Program Kemitraan Masyarakat (PKM) yang didanai oleh Direktorat Riset dan Pengabdian Masyarakat Kementerian Riset, Teknologi dan Pendidikan Tinggi tahun 2019.

\section{REFERENSI}

1. Depkes RI, 2008, Peraturan Menteri Kesehatan No. 269/MENKES/PER/III/2008 Tentang Rekam Medis, Jakarta.

2. Handiwidjojo, W., 2009, "Rekam Medis Elektronik", Jurnal EKSIS Vol 02 No 01 Mei 2009: halaman 36-41

3. Imamah, 2012, Perencanaan-Bidan-Praktek Mandiri BPM,

(http://imamah03.blogdetik.com/2012/01/11 /perencanaan-bidan-praktek-mandiri-bpm).

(diakses tanggal 18 Juni 2018)

4. Ambarwati, E., 2010, Tugas-dan-

Tanggungjawab-Bidan, (http://enyretnaambarwati.blogspot.com/201 0/02/tugas-dan-tanggungjawab-bidandi.html)(diakses tanggal 18 Juni 2018)

5. Juwitaningsih, dkk., 2013, Asuhan Kebidanan Ibu I (Kehamilan). DIV Kebidanan STIKES Ngudi Waluyo Ungaran

6. P. Chuan., 2014, "Design of Electronic Medical Record System Based on Cloud Computing Technology", TELKOMNIKA Indones. J. Electr. Eng., vol. 12, no. 5, pp. 4010-4017

7. C. Pan, J. Hu, and J. Shi, 2014, "Partitioning of Oracle Application in Structured Electronic Medical Records", TELKOMNIKA Indones. J. Electr. Eng., vol. 12 , no. 7, pp. 5693-5698

8. A. N. Kho et al., 2012, "Use of diverse electronic medical record systems to identify genetic risk for type 2 diabetes within a genome-wide association study", J. Am. Med. Informatics Assoc., vol. 19, no. 2, pp. 212-218

9. B. E. Purnama and A. Ashari, 2013, "Distributed Data Patient In Medical Record Information System", J. Sci. Technol. Res., vol. 2 , no. 8

10. Y. U. Khasanah, 2011, "Perencanaan Sistem Rekam Medis Berdasarkan Input Puskesmas Banguntapan II Kabupaten Bantul Tahun 2011", KES MAS, vol. 5, no. 1, pp. 55-71

11. G. W. Sasmito, 2017, "Penerapan Metode Waterfall Pada Desain Sistem Informasi Geografis Industri Kabupaten Tegal," $J$. Inform. Pengemb. IT, vol. 2, no. 1, pp. 6-12

12. Tominanto, E. Purwanto, and N. Yuliani, 2018, "Outpatient Electronic Medical Records", International Conference on 
Applied Science and Engineering (ICASE) 2018, Atlantis Press

13. M. Komarudin, 2016, "Pengujian Perangkat Lunak Metode Black-Box Berbasis Equivalence Partitions Pada Aplikasi Sistem Informasi Sekolah" Mikrotik, vol. 6, no. 1, 2016. 